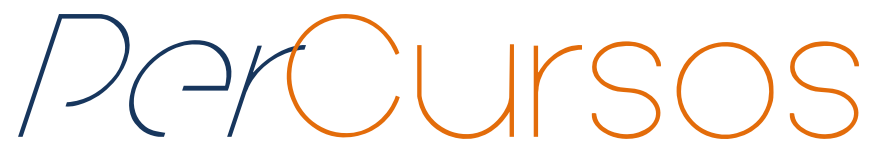

\title{
Direitos fundamentais do trabalho no contexto do projeto da nova lei de migração Brasileira
}

\section{Resumo}

O texto discute disposições de Projeto de Lei que busca instituir uma nova Lei de Migrações no Brasil e que se encontra em tramitação no Congresso Nacional. É enfatizado o aspecto dos direitos fundamentais trabalhistas dos trabalhadores imigrantes, pois na atual redação do Projeto tais direitos não são plenamente garantidos, já que é feita distinção entre imigrantes registrados e não registrados. É explicado que tal distinção é inconstitucional e contrária a compromissos internacionais ratificados pelo Brasil.

Palavras-chave: Direitos fundamentais do trabalho; Migração internacional; Brasil.
Gabrielle Louise Soares Timóteo

Doutora em Direito do Trabalho pela Universidade de São Paulo USP. Advogada. Professora de

Pós-graduação em Direito na Escola Superior de Advocacia de São Paulo - ESA-OAB/SP. Brasil

gabilouise@gmail.com 


\title{
Fundamental labour rights in the new Brazilian migration bill
}

\begin{abstract}
The paper analyses provisions of a Bill that is being discussed in the Congress and that intends to establish a new Migration Act in Brazil. The matter of fundamental labour rights of immigrant workers is emphasized because the current Bill does not fully guarantee such rights since it has been made difference between registered and unregistered immigrants. It is explained that this distinction is unconstitutional and opposed to international commitments ratified by Brazil.
\end{abstract}

Keywords: Fundamental labour rights; International migration; Brazil.

\section{Para citar este artigo:}

TIMÓTEO, Gabrielle Louise Soares. Direitos fundamentais do trabalho no contexto do projeto da nova lei de migração Brasileira. Revista PerCursos. Florianópolis, v. 16, n.32, p. 85 - 102, set./dez. 2015.

\section{DOI: $10.5965 / 1984724616322015085$}

http://dx.doi.org/10.5965/1984724616322015085 


\section{Uma nova lei de migração'}

O principal instrumento a regular a imigração no Brasil é a Lei $n^{\circ} 6.815$, de 1980, também conhecida como "Estatuto do Estrangeiro". Entretanto, tal legislação não se coaduna com diversos princípios presentes na Constituição Federal de 1988 e com normativos internacionais de Direitos Humanos ratificados pelo Brasil ao longo das últimas décadas. O Estatuto do Estrangeiro, elaborado durante o governo militar, possui abordagem calcada na segurança nacional e no controle de acesso ao mercado de trabalho. Nesse sentido, dispõe seu art. $2^{\circ}$ : “Na aplicação desta Lei atender-se-á precipuamente à segurança nacional, à organização institucional, aos interesses políticos, socioeconômicos e culturais do Brasil, bem assim à defesa do trabalhador nacional" (BRASIL, 1980).

Vale notar que o próprio termo "estrangeiro" possui conotação pejorativa, pois em nossa língua, em sentido figurado, ele se relaciona a "estranho" (HOUAISS, 2012). Segundo a psicóloga Marie-Louise von Franz, em sociedades primitivas o estranho geralmente estava associado ao perigo e à atmosfera da doença, do homicídio, dos distúrbios nas relações humanas e, por isso, era tratado com todo tipo de precauções (2002, p. 199 a 201). Como imigrantes geralmente são pessoas com características raciais, étnicas e culturais distintas da maioria da população local eles trazem consigo o potencial de causar estranhamento e aversão nos nacionais do país receptor.

Freud, no início do século XX, observou que indivíduos apoiam-se em suas pequenas diferenças para se distinguir das demais pessoas. Segundo ele, nessas pequenas diferenças fundamentam-se sentimentos de estranheza e hostilidade. Por vezes, pessoas que podem até parecer muito próximas para um observador externo

\footnotetext{
${ }^{1}$ A migração de que trataremos no presente texto é a migração de caráter internacional, ou seja, quando um indivíduo se translada de determinado Estado-nação a outro. Desta forma, os migrantes a que iremos nos referir são os migrantes internacionais. Um migrante internacional é emigrante na perspectiva do país do qual sai (Estado de origem) e é imigrante sob a perspectiva do país no qual chega (Estado de destino ou receptor). O status migratório, por sua vez, pode ser definido como a situação jurídica em que se encontra um imigrante frente às leis do Estado receptor. Assim, define-se o imigrante regular (ou documentado) como o indivíduo que está a observar as leis de migração do Estado receptor. Em oposição, o imigrante irregular (ou indocumentado) é o que se encontra em desconformidade com as disposições da legislação migratória do Estado receptor.
} 
acabam por se enxergar de forma sensivelmente distinta uma da outra. Apoiando-se em pequenas diferenças, podem construir sentimentos de repulsa e hostilidade entre si. $\mathrm{Na}$ passagem abaixo, Freud exemplifica situações que demonstram a existência de um "narcisismo das pequenas diferenças":

[...] Toda vez que duas famílias se unem por casamento, cada uma delas se acha melhor ou mais nobre que a outra. Havendo duas cidades vizinhas, cada uma se torna a maldosa concorrente uma da outra; cada pequenino cantão olha com desdém para o outro. Etnias bastante aparentadas se repelem, o alemão do sul não tolera o alemão do norte, o inglês diz cobras e lagartos do escocês, o espanhol despreza o português. Já não nos surpreende que diferenças maiores resultem numa aversão difícil de superar, como a do gaulês pelo germano, do ariano pelo semita, do branco pelo homem de cor. (2011, p. 57)

A intensificação dos fluxos migratórios nas últimas décadas no contexto de globalização econômica expôs largamente as diferenças entre as pessoas. Este processo tem, inclusive, consequências para as identidades culturais. Conforme esclarece Hall (2013, p. 49),

As identidades, concebidas como estabelecidas e estáveis, estão naufragando nos rochedos de uma diferenciação que prolifera. Por todo o globo, os processos das chamadas migrações livres e forçadas estão mudando de composição, diversificando as culturas e pluralizando as identidades culturais dos antigos Estados-nação dominantes, das antigas potências imperiais, e, de fato, do próprio globo.

Ocorre que essa diferenciação motiva, por parte de alguns indivíduos, a intensificação de preconceitos, de discriminação, de intolerância e de violência para com o “outro”. Na realidade, porém, como bem ressalta Farena, é inegável que as migrações “enriquecem a cultura local, estimulam a criar e recriar, a crescer e reaprender" (2012, p. 38).

Assim, um dos grandes desafios de nossos tempos parece ser reconhecer no “outro" um igual, um ser humano dotado da mesma dignidade em um globo permeado pelas diferenças e pelas migrações internacionais. Em outras palavras, efetivar os 
preceitos de proteção à dignidade humana consagrados em normativos internacionais de Direitos Humanos é um horizonte a ser constantemente perseguido.

Desta forma, o Brasil, considerando o atual cenário de migrações internacionais do século XXI, identificou a necessidade de adoção de uma nova lei migratória que estivesse em harmonia com preceitos de nossa vigente Constituição e dos tratados internacionais ratificados pelo país. O objetivo brasileiro é caminhar na direção de garantir os direitos humanos dos migrantes. Tanto o Executivo quanto o Legislativo brasileiros têm estudado a questão sob esse prisma. Da perspectiva do Executivo, destacamos a criação de uma Comissão de Especialistas, a qual apresentou em julho de 2014 um interessante anteprojeto de lei de migrações (RAMOS, 2014) e desde a perspectiva do Legislativo, ressaltamos o Projeto de Lei do Senado n²88/13 (“PLS 288/13"). Neste presente artigo, restringiremos nossa análise ao PLS 288/13 que ora tramita na Câmara dos Deputados sob a denominação de Projeto de Lei n 2.516 de 2015 (“PL 2516/15”) (BRASIL, 2015a).

\section{Projeto de lei do Senado $n^{\circ} 288 / 13$}

Cabe esclarecer que o PLS 288/13 busca uma mudança de paradigma na política migratória brasileira, deixando de centrá-la na segurança nacional para dar foco à proteção e prevalência dos direitos humanos dos migrantes. A referida proposta legislativa, apresentada em 11 de julho de 2013, é de autoria do Senador Aloysio Nunes Ferreira e seu texto inicial sofreu sensíveis modificações durante o período de tramitação no Senado Federal. O texto final aprovado no Senado foi encaminhado à Câmara dos Deputados em 04 de agosto de 2015 e, no momento em que escrevemos o presente artigo, a proposta legislativa em questão encontra-se em tramitação na Câmara sob a denominação de Projeto de Lei $n^{\circ} 2.516$ de 2015 (“PL 2516/15”), como já ressaltado (BRASIL, 2015a). Desta forma, ao longo deste trabalho faremos referências com intuito comparativo ao que identificaremos como texto inicial do PLS 288/13 e texto final do PLS $288 / 13$, entendendo que este texto final corresponde ao texto aprovado pelo Senado e ao atual teor do PL 2516/15 (em tramitação na Câmara, como dito) (BRASIL, 2015b). 
Assim sendo, importa evidenciar que o texto inicial do PLS 288/13 deixava claro, em seu art. $2^{\circ}$, inciso III, que um dos princípios a reger a política migratória brasileira seria o de "não criminalização da imigração", ou seja, o imigrante não seria punido criminalmente em razão de entrada irregular no país, pois isto seria, na verdade, uma infração administrativa e não um crime (BRASIL, 2014). Além do citado princípio, o art. $2^{\circ}$ do texto inicial do PLS 288/13 dispunha em sua íntegra que a política migratória brasileira reger-se-ia pelos seguintes princípios:

Art. $2^{\circ} \mathrm{A}$ política migratória brasileira rege-se pelos seguintes princípios:

I - interdependência, universalidade e indivisibilidade dos direitos humanos dos imigrantes, decorrentes de tratados dos quais o Brasil seja parte;

II - repúdio à xenofobia, ao racismo e quaisquer formas de discriminação; III - não criminalização da imigração;

IV - não discriminação quanto aos critérios e procedimentos de admissão de imigrantes no território nacional;

$\mathrm{V}$ - promoção de entrada regular e de regularização migratória;

$\mathrm{VI}$ - acolhida humanitária;

VII - incentivo à admissão de mão de obra especializada necessária ao desenvolvimento econômico, social, cultural, científico e tecnológico do Brasil, à captação de recursos e à geração de emprego e renda;

VIII - facilitação de entrada temporária de estrangeiros a fim de estimular o comércio, o turismo, as relações internacionais e as atividades culturais, esportivas, científicas e tecnológicas;

IX - garantia do direito a reunião familiar dos imigrantes;

$X$ - igualdade de tratamento e de oportunidade aos imigrantes, sem prejuízo de tratado mais benéfico que o disposto nessa lei;

$\mathrm{XI}$ - integração dos imigrantes documentados ou regulares no trabalho e na sociedade brasileira mediante política pública específica;

XII - acesso igualitário e livre aos serviços sociais, bens públicos, saúde, educação, justiça, trabalho, moradia, serviço bancário, emprego e previdência social;

XIII - promoção e difusão dos direitos, liberdades, garantias e obrigações dos imigrantes;

XIV - diálogo social na definição de políticas migratórias e promoção da participação dos imigrantes nas decisões públicas;

XV - fortalecimento da integração econômica, política, social e cultural dos povos da América Latina, mediante constituição de espaços de cidadania e livre-circulação de pessoas;

XVI - cooperação internacional com Estados de origem, trânsito e destino de movimentos migratórios a fim de garantir maior proteção de direitos humanos dos migrantes;

XVII - promoção da justiça internacional penal e combate ao crime organizado transnacional. 
Ainda que pontualmente fosse possível discutir as disposições dos incisos VII e XI na tentativa de aperfeiçoá-los ${ }^{2}$, vale destacar que foram estabelecidos princípios muito positivos que iam ao encontro dos anseios dos imigrantes presentes em nosso território ${ }^{3}$, tais como a já citada não criminalização da migração, o repúdio à xenofobia e discriminação, a acolhida humanitária, a reunião familiar, o acesso igualitário e livre aos serviços sociais, bens públicos, saúde, educação, justiça, trabalho, moradia, serviço bancário, emprego e previdência social.

Ademais, o artigo terceiro dispunha sobre os direitos e garantias dos migrantes também trazendo disposições avançadas, em conformidade com a constituição brasileira e com normativos internacionais ratificados pelo Brasil. Vejamos:

Art. $3^{\circ}$ Ao imigrante é garantida, em condição de igualdade com os nacionais, a inviolabilidade do direito à vida, à liberdade, à igualdade, à segurança e à propriedade, bem como assegurados:

I - direitos e liberdades civis, sociais, culturais e econômicos;

II - direito a liberdade de circulação no território nacional;

III - direito à reunião familiar dos imigrantes com seus cônjuges e companheiros, filhos e familiares dele dependentes;

IV - medidas de proteção às vítimas e testemunhas de tráfico de pessoas e de migrantes;

$V$ - direito de transferir recursos decorrentes de sua renda e economias pessoais a seu país de origem, observada a legislação aplicável;

$\mathrm{VI}$ - direito de reunião para fins pacíficos;

VII - direito de associação para fins lícitos;

VIII - acesso aos serviços públicos de saúde e de assistência social, nos termos da lei;

IX - amplo acesso à justiça, inclusive com concessão de gratuidade, desde que cumpridos os requisitos legais;

$X$ - acesso à educação;

$\mathrm{XI}$ - garantia de cumprimento de obrigações legais e contratuais trabalhistas e de aplicação das normas de proteção ao trabalhador;

XII- medidas destinadas a promover a integração do imigrante nas respectivas comunidades locais.

\footnotetext{
${ }^{2}$ No caso do inciso VII do art. $2^{\circ}$ acima citado seria possível debater a restrição feita a "mão de obra especializada" e no caso do inciso XI do mesmo artigo seria adequado discutir a restrição trazida pelos vocábulos "documentados" e "regulares".

3 Segundo estatísticas da Polícia Federal de março de 2015, existem no Brasil 1.847.274 (um milhão oitocentos e quarenta e sete mil e duzentos e setenta e quatro) imigrantes regulares. Os imigrantes irregulares, entretanto, não figuram nas estimativas oficiais (ARANTES, 2015).
} 
Parágrafo único. Os direitos e garantias previstos nesta Lei serão exercidos em observância ao disposto na Constituição, independentemente da situação migratória, e não excluem outros decorrentes de tratados ou convenções internacionais de que o Brasil seja parte, da legislação interna ordinária, de regulamentos expedidos pelas autoridades administrativas competentes, bem como dos que derivem dos princípios gerais do direito, analogia, costumes e equidade.

Destacamos que o parágrafo único do artigo acima é muito claro ao dispor que os direitos e garantias previstos na Lei seriam exercidos independentemente da situação migratória, ou seja, todos os imigrantes presentes em território brasileiro poderiam exercer os direitos assegurados pela Lei, pouco importando se ele seria qualificado de imigrante regular, irregular, documentado, indocumentado, registrado, não registrado, legal, ilegal ou qualquer outra denominação que se quisesse dar. O status migratório, assim, nesse contexto, não poderia ser considerado como um dado relevante para fundamentar restrição de direitos ou garantias.

Entretanto, como dito, o texto inicial do PLS 288/13 foi sensivelmente modificado durante sua tramitação no Senado Federal. Em dado momento, a Comissão de Relações Exteriores e Defesa Nacional apresentou parecer opinando pela aprovação do PLS 288/13 na forma de emenda substitutiva, a qual diferia em diversos pontos do texto inicial do PLS. Referida emenda apresentava novo texto que perfazia o total de 96 artigos (BRASIL, 2015C). O PLS seguiu sendo discutido no Senado e passou a contar com artigos adicionais. Em 04 de agosto de 2015, o texto final do PLS 288/13 aprovado no Senado foi enviado à Câmara e lá se encontra em tramitação, como já esclarecido (BRASIL, 2015d).

Diversos aspectos do Projeto merecem debate mais aprofundado na Câmara para que o texto seja aperfeiçoado no sentido de mais garantia e promoção dos direitos humanos. Embora certas disposições do texto atual apresentem avanços em relação ao texto inicial do PLS 288/13, há, em outras, pontos de retrocesso. Como exemplo de avanço, destacamos a extensão da possibilidade de concessão de residência ao imigrante vítima de tráfico de pessoas, de trabalho escravo ou de violação de direito agravada por sua condição migratória (artigo 25, XV, do PL 2516/15), vez que no texto inicial do PLS 
288/13 era contemplada apenas a concessão de permanência à vítima de tráfico de pessoas (artigo $11^{\circ}$, IV, do texto inicial do PLS 288/13).

No presente trabalho, porém, temos como objetivo destacar um ponto específico que, em nossa visão, merece ser intensamente debatido na Câmara: a questão da garantia dos direitos trabalhistas fundamentais dos imigrantes, independentemente de seu status migratório. Assim sendo, passemos a analisar esta temática no item subsequente.

\section{Direitos fundamentais do trabalho no PL 2516/15}

O PL 2516/15, na mesma linha do texto inicial do PLS 288/13, também enuncia como princípios da política migratória que busca estabelecer inúmeras disposições avançadas. Vejamos:

Art. $3^{\circ} \mathrm{A}$ política migratória brasileira rege-se pelos seguintes princípios:

I - universalidade, indivisibilidade e interdependência dos direitos humanos;

II - repúdio e prevenção à xenofobia, ao racismo e a quaisquer formas de discriminação;

III - não criminalização da imigração;

IV - não discriminação em razão dos critérios ou dos procedimentos pelos quais a pessoa foi admitida em território nacional;

$\mathrm{V}$ - promoção de entrada regular e de regularização documental;

$\mathrm{VI}$ - acolhida humanitária;

VII - desenvolvimento econômico, turístico, social, cultural, esportivo, científico e tecnológico do Brasil;

VIII - garantia do direito à reunião familiar;

IX - igualdade de tratamento e de oportunidade ao migrante e seus familiares;

$\mathrm{X}$ - inclusão social, laboral e produtiva do migrante por meio de políticas públicas;

$\mathrm{XI}$ - acesso igualitário e livre do imigrante a serviços, programas e benefícios sociais, bens públicos, educação, assistência jurídica integral pública, trabalho, moradia, serviço bancário e seguridade social;

XII - promoção e difusão de direitos, liberdades, garantias e obrigações do migrante;

XIII - diálogo social na formulação, na execução e na avaliação de políticas migratórias e promoção da participação cidadã do migrante; 
XIV - fortalecimento da integração econômica, política, social e cultural dos povos da América Latina, mediante constituição de espaços de cidadania e de livre circulação de pessoas;

XV - cooperação internacional com Estados de origem, de trânsito e de destino de movimentos migratórios, a fim de garantir efetiva proteção aos direitos humanos do migrante;

$\mathrm{XVI}$ - integração e desenvolvimento das regiões de fronteira e articulação de políticas públicas regionais capazes de garantir efetividade aos direitos do residente fronteiriço;

XVII - proteção integral e atenção ao superior interesse da criança e do adolescente migrante;

XVIII - observância ao disposto em convenções, tratados e acordos internacionais;

XIX - proteção ao brasileiro no exterior;

$\mathrm{XX}$ - migração e desenvolvimento humano no local de origem, como direitos inalienáveis de todas as pessoas;

XXI - promoção do reconhecimento acadêmico e do exercício profissional no Brasil; e

XXII - repúdio a práticas de expulsão ou de deportação coletivas.

Da mesma forma, o PL 2516/15 também prevê um rol extenso de garantias aos imigrantes em seu artigo $4^{\circ}$ :

Art. $4^{\circ}$ Ao imigrante é garantida, em condição de igualdade com os nacionais, a inviolabilidade do direito à vida, à liberdade, à igualdade, à segurança e à propriedade, bem como:

I - direitos e liberdades civis, sociais, culturais e econômicos;

II - direito à liberdade de circulação em território nacional;

III - direito à reunião familiar do imigrante com seu cônjuge ou companheiro e seus filhos, familiares e dependentes;

IV - medidas de proteção a vítimas e testemunhas de crimes e de violações de direitos;

$\mathrm{V}$ - direito de transferir recursos decorrentes de sua renda e economias pessoais a outro país, observada a legislação aplicável;

$\mathrm{VI}$ - direito de reunião para fins pacíficos;

VII - direito de associação, inclusive sindical, para fins lícitos;

VIII - acesso a serviços públicos de saúde e de assistência social e à previdência social, nos termos da lei;

IX - amplo acesso à justiça e à assistência jurídica integral gratuita aos que comprovarem insuficiência de recursos;

X - direito à educação pública, vedada a discriminação em razão da nacionalidade;

$\mathrm{XI}$ - garantia de cumprimento de obrigações legais e contratuais trabalhistas e de aplicação das normas de proteção ao trabalhador;

XII - isenção das taxas de que trata esta Lei, mediante declaração de hipossuficiência econômica, na forma de regulamento; 
XIII - direito de acesso à informação, nos termos da Lei n ${ }^{\circ} 12.527$, de 18 de novembro de 2011;

XIV - direito a abertura de conta bancária; e

$X V$ - direito de sair, de permanecer e de reingressar em território nacional, mesmo enquanto pendente pedido de residência, de prorrogação de estada ou de transformação de visto em residência.

Entretanto, é essencial notar que o PL 2516/15, contrariamente ao texto inicial do PLS 288/13, estabelece ressalva acerca de direitos dos imigrantes, pois limita ao visitante e ao imigrante não registrado o exercício de alguns importantes direitos, como pode ser compreendido por meio da leitura atenta dos parágrafos $1^{\circ}, 4^{\circ}$ e $5^{\circ}$ do artigo $4^{\circ}$ do $\mathrm{PL}$ 2516/15. Desta forma, observa-se que embora o $\S 1^{\circ}$ deste referido artigo $4^{\circ}$ estabeleça que "os direitos e as garantias previstos nesta Lei serão exercidos em observância ao disposto na Constituição Federal, independentemente da situação migratória", tais direitos e garantias devem ser exercidos com base no "disposto nos $\S \S 4^{\circ}$ e $5^{\circ}$ deste artigo":

$\operatorname{Art.} 4^{\circ}[\ldots]$

$\S 1^{\circ}$ Os direitos e as garantias previstos nesta Lei serão exercidos em observância ao disposto na Constituição Federal, independentemente da situação migratória, observado o disposto nos $\S \S 4^{\circ}$ e $5^{\circ}$ deste artigo, e não excluem outros decorrentes de convenções, tratados e acordos internacionais de que o Brasil seja parte.

Neste ponto se apresenta a problemática do respeito aos direitos trabalhistas fundamentais dos imigrantes, pois os parágrafos $4^{\circ}$ e $5^{\circ}$ do artigo $4^{\circ}$, com o emprego de redação capciosa, afirmam que:

$\S 4^{\circ}$ Aplicam-se ao visitante os direitos previstos no caput e nos incisos I, II, IV, V, VI, VIII, IX, X, XIII, XIV e XV deste artigo.

$\S 5^{\circ}$ Aplicam-se ao imigrante não registrado os direitos previstos no caput e nos incisos I, II, IV, VI, VIII, X e XIII deste artigo.

Ora, se 0 artigo $4^{\circ}$ possui XV incisos enumerando direitos aos imigrantes, afirmar que se aplicam a determinadas categorias de imigrantes apenas alguns incisos deste artigo é o mesmo que afirmar que não se aplicam os direitos que não foram 
explicitamente citados nos parágrafos, ou seja, certos direitos são negados a determinados imigrantes em razão de seu status migratório ${ }^{4}$.

Desta forma, a leitura conjunta dos dispositivos acima tratados leva à conclusão de que não são aplicáveis aos visitantes os seguintes direitos previstos no art. $4^{\circ}$ : (a) direito à reunião familiar do migrante com seu cônjuge ou companheiro e seus filhos, familiares e dependentes (inciso III); (b) direito de associação, inclusive sindical, para fins lícitos (inciso VII); (c) garantia de cumprimento de obrigações legais e contratuais trabalhistas e de aplicação das normas de proteção ao trabalhador (inciso XI); (d) isenção das taxas de que trata esta Lei, mediante declaração de hipossuficiência econômica, na forma de regulamento (inciso XII). Também é possível concluir com base na atual redação do Projeto que não são aplicáveis aos imigrantes não registrados os seguintes direitos: (a) direito à reunião familiar do migrante com seu cônjuge ou companheiro e seus filhos, familiares e dependentes (inciso III); (b) direito de transferir recursos decorrentes de sua renda e economias pessoais a outro país, observada a legislação aplicável (inciso V); (c) direito de associação, inclusive sindical, para fins lícitos (inciso VII); (d) amplo acesso à justiça e à assistência jurídica integral gratuita aos que comprovarem insuficiência de recursos (inciso IX); (e) garantia de cumprimento de obrigações legais e contratuais trabalhistas e de aplicação das normas de proteção ao trabalhador (inciso XI); (f) isenção das taxas de que trata esta Lei, mediante declaração de hipossuficiência econômica, na forma de regulamento (inciso XII); (g) direito a abertura de conta bancária (inciso XIV); (h) direito de sair, de permanecer e de reingressar em território nacional, mesmo enquanto pendente pedido de residência, de prorrogação de estada ou de transformação de visto em residência (inciso $\mathrm{XV}$ ).

\footnotetext{
${ }^{4}$ A expressão "categorias de imigrantes" pode soar estranha para alguns à primeira vista. Entretanto lembremos que o Projeto de Lei em comento no presente artigo categoriza os imigrantes em "visitante", "registrado", "não registrado", por exemplo. Tal procedimento de divisão de imigrantes em categorias é comum em legislações migratórias no Brasil e no mundo. O atual Estatuto do Estrangeiro, por exemplo, distingue os imigrantes com base no tipo de visto que possuem. Exemplos de vistos na vigente legislação brasileira: de trânsito; de turista; temporário; permanente; de cortesia; oficial; diplomático (art. $4^{\circ}$, Lei 6.815/80). Algumas disposições da Lei lidam explicitamente com tais classificações e conferem ou restringem direitos com base na condição migratória do indivíduo estabelecida pelo seu visto ou por outra situação (ex.: arts. 30, 34, 35 etc.).
} 
Tais restrições apresentam impactos significativos no cotidiano dos imigrantes, sendo que algumas são flagrantemente inconstitucionais como, por exemplo, a limitação aos imigrantes não registrados de acesso à Justiça e de assistência jurídica integral gratuita aos que comprovarem insuficiência de recursos. O direito de acesso à Justiça é garantido pela Constituição Federal brasileira em seu art. $5^{\circ}$, inciso XXXV, que dispõe que “a lei não excluirá da apreciação do Poder Judiciário lesão ou ameaça a direito”. Já a assistência jurídica é objeto do inciso LXXIV, que determina que "o Estado prestará assistência jurídica integral e gratuita aos que comprovarem insuficiência de recursos" (BRASIL, 1988) ${ }^{5}$.

Assim sendo, seria importante que o PL 2516/15 não fosse aprovado com a redação atual também para se evitar judicialização de demandas, inclusive de ações direitas de inconstitucionalidade (“ADINs") no Supremo Tribunal Federal (“STF”).

Em relação ao tema específico de direitos fundamentais trabalhistas, é importante notar que a atual redação do PL 2516/15 não confere nem ao visitante, nem ao imigrante não registrado a "garantia de cumprimento de obrigações legais e contratuais trabalhistas e de aplicação das normas de proteção ao trabalhador". Tal exclusão é inaceitável sob a perspectiva dos direitos fundamentais do trabalho.

Os direitos fundamentais do trabalho não possuem relação com o status migratório do indivíduo. Segundo a Corte Interamericana de Direitos Humanos, os direitos laborais surgem necessariamente da condição de trabalhador, em sentido amplo. Desta forma, toda pessoa que vai realizar, realiza ou realizou uma atividade remunerada adquire imediatamente a condição de trabalhador e consequentemente, os direitos inerentes a tal condição. Em consequência, a capacidade de desempenho de uma atividade produtiva depende exclusivamente da capacidade e formação profissional, e

\footnotetext{
${ }^{5}$ Embora o caput do artigo $5^{\circ}$ apenas assegure de forma expressa direitos "aos brasileiros e aos estrangeiros residentes no país", conforme explicam Paulo e Alexandrino (2010, p. 113) "há consenso, entretanto, pela própria natureza de tais direitos, que eles valem igualmente para os estrangeiros que se encontrem em território nacional, submetidos às leis brasileiras, sejam eles residentes ou não no Brasil". Nesta mesma linha de raciocínio, Moraes (2010, p.34-35) esclarece que a expressão do art. $5^{\circ}$ "residentes no Brasil deve ser interpretada no sentido de que a Carta Federal só pode assegurar a validade e gozo dos direitos fundamentais dentro do território brasileiro, não excluindo, pois, o estrangeiro em trânsito pelo território nacional, que possui igualmente acesso às ações, como o mandado de segurança e demais remédios constitucionais [...]".
} 
em nenhum caso encontra-se vinculada à condição migratória das pessoas. A Corte ainda destaca que o Estado receptor ou seus particulares não estão obrigados a fornecer trabalho aos migrantes indocumentados. Entretanto, se estes são contratados, convertem-se imediatamente em titulares de direitos trabalhistas, sem que exista possibilidade de discriminação fundamentada no status migratório do trabalhador. A Corte também esclarece que são exemplos de direitos fundamentais do trabalho: direito à remuneração equitativa e satisfatória; direito a fundar sindicatos e a se sindicalizar; direito a garantias judiciais e administrativas para a persecução de seus direitos; proibição do trabalho forçado e infantil; jornada razoável; descanso; condições adequadas de trabalho (higiene e segurança do trabalho) etc. (INTER-AMERICAN COURT OF HUMAN RIGHTS, 2003).

Cabe ainda ressaltar que o Brasil pode ser responsabilizado internacionalmente pela Corte Interamericana de Direitos Humanos se permitir ou provocar uma violação contra os direitos humanos dos migrantes (FARENA, 2012, p. 97).

O Protocolo Adicional à Convenção Americana sobre Direitos Humanos em Matéria de Direitos Econômicos, Sociais e Culturais ("Protocolo de San Salvador") estabelece, por seu turno, diversos direitos trabalhistas, bem como garantias de condições justas, equitativas e satisfatórias de trabalho e também direito de se sindicalizar e de fazer greve ( $\operatorname{artigos} 6^{\circ}, 7^{\circ}$ e $8^{\circ}$ ). O Brasil promulgou tal normativo por meio do Decreto $n^{\circ} 3.321$ de 30 de dezembro de 1999 (BRASIL, 1999).

Ademais, o Brasil é Estado Membro da Organização Internacional do Trabalho (“OIT”), sendo que a Declaração da OIT sobre Princípios e Direitos Fundamentais no Trabalho, de 1998, estabelece que todos os Estados Membros da Organização devem respeitar e promover princípios e direitos relativos a: (i) liberdade sindical e reconhecimento efetivo do direito de negociação coletiva; (ii) eliminação de todas as formas de trabalho forçado ou obrigatório; (iii) abolição efetiva do trabalho infantil; e (iv) eliminação da discriminação em matéria de emprego e ocupação (OIT, 1998).

Este compromisso independe de terem os Estados ratificado convenções específicas nas áreas acima citadas, pois segundo a OIT, eles têm uma obrigação de 
respeitar tais princípios derivada do próprio fato de pertencerem à Organização. Em adição, a Declaração reconhece que apenas crescimento econômico não garante equidade, progresso social e erradicação da pobreza e ressalta que é necessário se prestar atenção a grupos com necessidades sociais especiais, em particular os desempregados e os trabalhadores migrantes (OIT, 1998).

Desta forma, o PL 2516/15 ao não garantir ao visitante e ao imigrante não regular o direito de associação sindical, o cumprimento de obrigações legais e contratuais trabalhistas, bem como a aplicação das normas de proteção ao trabalhador, fere frontalmente as premissas mais básicas do Direito do Trabalho. A manutenção da redação atual do PL 2516/15 leva à absurda interpretação de que um imigrante que laborou no país com status migratório irregular não teria direito a recorrer à justiça trabalhista para pleitear salários vencidos e não pagos, por exemplo. Fica patente, portanto, a insustentabilidade da restrição feita pelo $\mathrm{PL} 2516 / 15$ no que tange os direitos fundamentais trabalhistas dos imigrantes. Neste aspecto, o PL 2516/15 vai contra princípios que seu próprio texto diz buscar se pautar. Ademais, ao restringir direitos trabalhistas fundamentais, o PL 2516/15 também caminha em contrariedade com disposições da Constituição Federal, de normativos internacionais já ratificados pelo Brasil (tais como o Protocolo de San Salvador e a Declaração da OIT sobre Princípios e Direitos Fundamentais do Trabalho), contra a Opinião Consultiva $n^{\circ} 18$ da Corte Interamericana de Direitos Humanos e, ainda, contra disposições mais avançadas acerca da temática, como a Declaração da ONU sobre os Direitos dos Trabalhadores Migrantes e de suas Famílias (ainda pendente de ratificação pelo Brasil).

Nos últimos anos, o Brasil tem adotado medidas contra o trabalho em condições análogas à escravidão e contra o tráfico de pessoas para fins de exploração do trabalho, sendo que um dos possíveis fatores de vulnerabilidade das vítimas desses crimes é justamente o status migratório irregular. A repressão a essas práticas de exploração laboral devem estar focadas no combate aos empregadores que buscam se aproveitar da condição migratória precária de certas pessoas com o propósito de descumprir a legislação trabalhista e praticar condutas que podem caracterizar, inclusive, dumping social. Reconhecer a não incidência de direitos trabalhistas aos imigrantes não registrados 
e aos visitantes - como quer o PL 2516/15 - é um retrocesso na luta do governo e das autoridades públicas brasileiras contra o trabalho em condições análogas à de escravo e contra o tráfico de seres humanos.

Se um imigrante for submetido a violações de direitos fundamentais trabalhistas, ele deve ser reparado - independentemente de seu status migratório. Compreendemos que os parágrafos $4^{\circ}$ e $5^{\circ}$ do artigo $4^{\circ}$ deveriam ser eliminados do PL 2516/15 e que o parágrafo $1^{\circ}$ do citado artigo deveria ter a redação modificada para o teor que apresentava o texto inicial do PLS 288/13, ou seja, no sentido de refletir que o status migratório não é razão para se restringir direitos e garantias dos imigrantes.

\section{Conclusão}

Diante das considerações acima expostas, podemos concluir que o debate sobre a questão dos direitos fundamentais dos trabalhadores no contexto do projeto de uma nova lei de migrações brasileira precisa ser intensificado e aprofundado na Câmara dos Deputados para que possamos, efetivamente, implementar uma política migratória mais humanizada com foco no combate à situação de vulnerabilidade dos migrantes.

\section{Referências}

ARANTES, José Tadeu. O panorama da imigração no Brasil. Revista Exame.com, 07. jul. 2015. Disponível em: < http://exame.abril.com.br/brasil/noticias/o-panorama-da-imigracaono-brasil >. Acesso em 25 de janeiro de 2016.

BRASIL. Câmara dos Deputados. Andamento do Projeto de Lei n ${ }^{\circ} 2.516$ de 2015. Institui a Lei de Migração. 2015a. Disponível em: < http://www.camara.gov.br/proposicoesWeb/fichadetramitacao?idProposicao=1594910 >. Acesso em: 31. ago. 2015.

BRASIL. Câmara dos Deputados. Projeto de Lei nº 2.516 de 2015. Institui a Lei de Migração. 04. ago. 2015b. Disponível em: < http://www.camara.gov.br/proposicoesWeb/prop mostrarintegra;jsessionid=0F5B5D95A3A EE0A17BB5267A3EE50D4A. proposicoesWeb2?codteor $=1366741 \&$ filename $=P L+2516 / 2015>$ . Acesso em: 31. ago. 2015. 
BRASIL. Constituição Federal de 5 de outubro de 1988. Disponível em: < http://www.planalto.gov.br/ccivil 03/constituicao/constituicao.htm >. Acesso em: 28 out. 2015.

BRASIL. Decreto no 3.321 de 30 de dezembro de 1999. Promulga o Protocolo Adicional à Convenção Americana sobre Direitos Humanos em Matéria de Direitos Econômicos, Sociais e Culturais "Protocolo de São Salvador". Disponível em: < http://www.planalto.gov.br/ccivil 03/decreto/D3321.htm >. Acesso em: 26 jan. 2016.

BRASIL. Lei ${ }^{\circ}$ 6.815, de 19 de agosto de 1980. Define a situação jurídica do estrangeiro no Brasil, cria o Conselho Nacional de Imigração. Disponível em: < http://www.planalto.gov.br/ccivil 03/Leis/L6815.htm >. Acesso em: 29 out. 2015.

BRASIL. Senado Federal. Andamento do Projeto de Lei do Senado no 288 de 2013. 2015c. Disponível em: < http://www25.senado.leg.br/web/atividade/materias//materia/113700 >. Acesso em: 31. ago. 2015.

BRASIL. Senado Federal. Texto final do Projeto de Lei do Senado no 288 de 2013. 07. jul. 2015d. Disponível em: < http://legis.senado.leg.br/mateweb/arquivos/matepdf/172059.pdf >. Acesso em: 31.ago.2015.

BRASIL. Senado Federal. Texto inicial do Projeto de Lei do Senado ${ }^{\circ} 288$ de 2013. 27. mar. 2014. Disponível em: < http://www25.senado.leg.br/web/atividade/materias//materia/113700>. Acesso em: 31. ago. 2015.

FARENA, Maritza. Direitos humanos dos migrantes: ordem jurídica internacional e brasileira. Curitiba: Juruá, 2012.

FRANZ, Marie-Louise von. A sombra e o mal nos contos de fada. São Paulo: Paulus, 2002.

FREUD, Sigmund. Psicologia das massas. In: Psicologia das massas e análise do Eu e outros textos (1920-1923). Obras completas, v. 15. São Paulo: Companhia das Letras, 2011.

HALL, Stuart. Da diáspora: identidades e mediações culturais. $2^{\mathrm{a}}$ ed. Belo Horizonte: UFMG, 2013.

HOUAISS (Dicionário). Estrangeiro. 2012. Disponível em: < http://houaiss.uol.com.br/busca?palavra=ESTRANGEIRO >. Acesso em: 31. ago. 2015.

INTER-AMERICAN COURT OF HUMAN RIGHTS. Advisory Opinion OC-18/03 of September 17, 2003. Juridical Condition and Rights of Undocumented Migrants. Disponível em: < http://www.corteidh.or.cr/docs/opiniones/seriea 18 ing.pdf >. Acesso em: 28 out. 2015. 
MORAES, Alexandre de. Direito Constitucional. 26 ed. São Paulo: Atlas, 2010.

OIT. Declaração da OIT sobre Princípios e Direitos Fundamentais no Trabalho. 1998.

Disponível em: <http://www.oitbrasil.org.br/info/downloadfile.php?fileld=356 >. Acesso em: 31.mar.2009.

PAULO, Vicente; ALEXANDRINO, Marcelo. Direito Constitucional Descomplicado. $6^{\mathrm{a}}$ ed. São Paulo: Método, 2010.

RAMOS, André de Carvalho et al. "Anteprojeto de Lei de Migrações e promoção dos direitos dos migrantes no Brasil". 2014. Disponível em: $<$ http://library.fes.de/pdf-

files/bueros/brasilien/10947.pdf >. Acesso em: 31. ago. 2015.

Recebido em: 29/10/2015

Aprovado em: 27/01/2016

Universidade do Estado de Santa Catarina - UDESC

Centro de Ciências Humanas e da Educação - FAED

Revista PerCursos

Volume 16 - Número 32 - Ano 2015

revistapercursos@gmail.com 